\title{
Generational Portrait of Spanish Society in the Face of Climate Change. A Question to Consider for the Green Economy under the Well-Being Approach
}

\author{
María-José Foncubierta-Rodríguez ${ }^{1}$ (D), Rafael Ravina-Ripoll ${ }^{2, * \mathbb{D}}$ and José Antonio López-Sánchez ${ }^{3}$ (D) \\ 1 Department of Business Organization, University of Cádiz, 11202 Algeciras, Spain; \\ mariajose.foncubierta@uca.es \\ 2 Department of Business Organization and INDESS, University of Cádiz, 11405 Jerez de la Frontera, Spain \\ 3 Department of History, Geography and Philosophy and INDESS, University of Cádiz, \\ 11405 Jerez de la Frontera, Spain; joseantonio.lopez@uca.es \\ * Correspondence: rafael.ravina@uca.es
}

Citation: Foncubierta-Rodríguez,

M.-J.; Ravina-Ripoll, R.;

López-Sánchez, J.A. Generational

Portrait of Spanish Society in the Face of Climate Change. A Question to Consider for the Green Economy under the Well-Being Approach. Energies 2021, 14, 807. https:// doi.org/10.3390/en14040807

Academic Editor: Luisa Cabeza

Received: 8 January 2021

Accepted: 29 January 2021

Published: 3 February 2021

Publisher's Note: MDPI stays neutral with regard to jurisdictional claims in published maps and institutional affiliations.

Copyright: (c) 2021 by the authors. Licensee MDPI, Basel, Switzerland. This article is an open access article distributed under the terms and conditions of the Creative Commons Attribution (CC BY) license (https:/ / creativecommons.org/licenses/by/ $4.0 /)$.

\begin{abstract}
Climate change is emerging as an issue of progressive attention, and therefore awareness, in societies. In this work, the problem is addressed from a generational perspective in Spanish society and is carried out from the approaches of awareness, human action, and self-responsibility. All this from the search of the subjective well-being and the citizens' happiness, as one of the bases of sustainable development initiatives. With data from the European Social Survey R8, from EUROSTAT, we work in two phases: (1) descriptive and inferential on possible associations of the items with the variable Age, and (2) calculation of probabilities between groups through logistic regression. The results confirm a general awareness, but with apparent statistical differences between age groups. In general, the youngest are the most aware, blame human activity most intensely, are the most concerned, and are the most willing to act. And it is the older people who are less aware of all these issues. Based on this finding, and from the approach mentioned above, it is recommended that leaders, both in the macroeconomic and microeconomic sectors, develop initiatives that sensitize and encourage older age groups.
\end{abstract}

Keywords: climate change; climate change awareness; EU; Green Deal; reduction of polluting energies; well-being economy; happiness management

\section{Introduction}

Climate change is currently an essential topic of analysis and study on political agendas and public opinion. It has been raised by many researchers [1-4] as one of the most pressing issues for the 21st century.

According to Article 1 of the United Nations Framework Convention on Climate Change, climate change is a change of climate attributed directly and indirectly to human activity that alters the global atmosphere's composition and adds to natural climate variability observed over long periods [5,6]. The term is also sometimes used to refer specifically to climate change caused by human activities, rather than changes in climate resulting from the Earth's natural processes $[7,8]$. The scientific community is therefore beginning to use the term "Anthropocene" to characterize this new era of anthropogenic influence on the earth $[9,10]$ with the aim, among others, of making the authorities aware of this reality and taking measures to mitigate the impacts of $C C$ that are now considered irreversible [11]. In this connection, therefore, especially in the context of environmental policies, climate change is regarded as a synonym for global warming [12,13].

Global awareness of this issue was first raised by the Kyoto Protocol, adopted on 11 December 1997, which is based on the principles of other treaties but, above all, has its roots in the United Nations Framework Convention on Climate Change 1994, which com- 
mitted industrialized countries and economies in transition to limit and reduce greenhouse gas (GHG) emissions by agreed-upon individual targets.

In 2007, the Fourth Assessment Report of the Intergovernmental Panel on Climate Change [14,15] stated that "the warming of the climate system is unequivocal, as evidenced by the average temperatures of the atmosphere and the oceans, the melting of snow and ice and the global rise in average sea levels. For this reason, climate change, global warming, and sustainability are integrated into the United Nations' agenda and the countries that have signed these protocols. In 2015, the United Nations approved the 2030 sustainable development goals [16]. With a series of global objectives to eradicate poverty, protect the planet, and ensure prosperity.

In its report Millennium Development Goals [17], the United Nations, like other researchers [18,19], concludes that most of the impacts of climate change are local, although the studies normally provide models of impact on global geography, such as the "FastTrack" analysis conducted by Arnell, 2004; Nicholls, 2004; Parry et al., 2004; Van Lieshout et al., 2013 [20-25]. The international discourse on climate change has increasingly become a priority for research and ministerial policies [25-31]. Some academics are beginning to propose in their study that people have started to adopt the new climate reality as it is starting to be perceived as inevitable [32-35], especially by the youngest.

In this context, current society is undergoing a significant transformation from the point of view of bioregionalism and presents, especially the youngest, a new mentality regarding how to act, among other reasons, because it is experiencing a technological revolution a climate crisis [36,37], the incorporation of climate change and sustainability as fundamental aspects for future generations' development is causing a difference in current social research paradigms.

In this sense, the correlates of the environmental behaviors of young people adopt a relational chronological perspective. Firstly, ecological values are discovered in the family. Later, through social networks, these socialization aspects are promoted as critical factors in modeling individuals' attitudes and environmental behaviors [38-42]. Everyday practices that have consequences for the environment, such as recycling, reducing energy and water consumption, or reusing materials, are often learned in these areas.

Moreover, as is well known, we are moving towards a new economic model where increasingly differentiating aspects of the traditional market model prevail. A more significant consideration is given to the sustainable nature of the productive activity to preserve ecosystems. According to this vision, the green economy concept emerged at the end of the 20th century. A field of economics that maintains, among other things, that the emotional level of happiness of citizens will be higher in territories that cultivate an industrial activity based on the sustainable development of renewable energies [43]. Hence, companies need to undertake the organizational culture of Happiness Management as a portfolio of sustainability, eco-innovation, social responsibility, and collective well-being [44].

Based on everything read so far, it is not surprising that public governance advocates creating a legislative framework to achieve production based on renewable energies to mitigate climate change effects $[45,46]$, all these considerations, already either directly or indirectly, are increasingly present among the new generations [47].

Along these lines, in 2015 the United Nations approved the Agenda 2030 on Sustainable Development [16], creating a path aimed at improving and preserving life and the planet's ecosystems, whose overall objective is to create a world with the improvements and amenities needed not only for current generations but also for future generations.

All these new regulations and elements impact global policies and on changing the mindset of citizens. Despite this firm commitment by governments, institutions, administrations, etc., recent studies show that climate change education is not present in most Western countries' educational curriculum. Therefore, it must be adapted in terms of content, framework, and methods, on the one hand, to the ODS. On the other hand, it must also be adjusted to the particular preconditions of the potential target groups [36-45], i.e., society in general and young people, mainly if a real social transformation is to be achieved 
in this regard. Aware of this, many educational programs aim to increase people's literacy on climate change [48].

The objective of this paper is to search for and describe the relationship between the age of society's members in Spain and the items of climate change, that is, whether the response to these items is associated with belonging to a particular age group. Specifically, the aim is to determine whether these relationships lead to age groups that are more aware of and concerned about climate change and take greater responsibility for mitigating it. Especially if, as reflected in the literature, young people are most proactive in this regard, or if new findings are discovered that may involve the other age groups. In fact, in a study conducted by Gifford on 18 countries, it is stated that people tend to believe that socio-environmental conditions are worse in countries other than their own and, of course, people in those countries tend to think the same about other countries [49]. When problems are assumed to be worse elsewhere, people, especially if they are older, are less motivated to improve their environment. Future environmental risks are also often ruled out [50] because of a lack of knowledge or training.

In contrast, there is a greater awareness of young Westerners. They live in a technologically advanced, digital, and global world and are experiencing the environmentalist initiation in which Western society is immersed. It would partly explain why young people are considering specific issues not only on a regional but also on a global scale.

Based on these cognitive evidences, the following hypotheses are formulated:

Hypothesis 1. The youngest searched group of people in Spain is the most aware of climate change compared to the middle, the mature, and the elderly aged.

Hypothesis 2. The youngest searched group of people in Spain is the most aware that climate change is caused by human action compared to the middle, the mature, and the elderly.

Hypothesis 3. The youngest searched group of people in Spain is a group which is the most concerned about climate change in comparison to the middle, the mature and the elderly aged.

Hypothesis 4. The youngest searched group of people in Spain is a group that feels a more personal responsibility to reduce climate change in comparison to the middle, the mature, and the elderly aged.

For each of these hypotheses, there is a null hypothesis (H0) whose statement would be: There is no association between the values of the dependent variable $i$ and the categories of the variable Age. That is, there are no statistically significant differences between the averages of the age categories; these are similar.

This study is structured in the following way: after the Introduction, in the second section, the hypotheses are raised. The methodology used is indicated, as well as the statistical sources considered. The third section presents the results obtained in the study carried out. The fourth section formally examines the existing discussions on the subject. The most important conclusions obtained in this study will be compiled in the last quarter.

\section{Materials and Methods}

Within the current European statistical framework, the European Social Survey (ESS) constitutes a secondary information sources that offer a rich amount of quantitative data directly linked to our research topic. Since 2001, these surveys have been carried out biannually by the European Statistical Office (Eurostat) to collect information on the attitudes, beliefs, and behavioral patterns of European, Russian and Israeli citizens on education, politics, and justice, religion, etc. [51]. It should also be noted that questionnaires are currently a statistical instrument widely used by public institutions for their socioeconomic analyses because they guarantee the quality of the information collected and offer the possibility of extrapolating that questionnaire to other territories with the utmost inferential soundness.

This article has used Round 8 of the European Social Survey (ESS) as a data source [52]. This choice is motivated because it is the most updated questionnaire elaborated by Euro- 
stat, which contains information on the following thematic areas: climate change, energy security, environmental policy, and energy preferences [53]. This survey was carried out between August 2016 and December 2017, resulting in a cross-national sample population of 44.387 participants. These were chosen at random after applying the corresponding post-stratification and population weighting coefficients [54].

In this sense, it should be noted that the interviews were conducted in person with people over 15 years of age living in 23 countries with advanced economies, including Spain. This eliminates the potential problem of common method variance, which is characteristic of self-administered surveys $[55,56]$. In the ecosystem that is the object of our study, this scientific survey was carried out by the Sociological Research Center (SRC), once the SSE questionnaire had been adapted to the Spanish environment and language. The sampling procedure applied in this country has been multi-stage, stratified by conglomeration (two stages), in which the strata are obtained using two crossed criteria: habitat size (classified in four sections) and Autonomous Community (including the autonomous cities of Ceuta and Melilla). As for the selection of the individuals interviewed, it should be noted that random probabilistic methods were used, which were carried out by the National Institute of Statistics (INE) in Spain.

According to the information obtained by the ESS8 database (Spain) and the bibliographic review of the literature, the present academic research aims to undertake a relational analysis, both non-parametric and parametric, and logistic regression, with the use of the SPSS software, version 27. This paper's methodological strategy is similar to that applied by previous quantitative studies using the European Social Survey (ESS) Round 8 . These include Gómez-Román et al., 2021; Dias et al., 2020; Rubio-Valverde et al., 2019 and Ayalon et al., 2014, among others [57-60].

The items that support the hypotheses raised are those described in Table 1. The ranges of values and the code with which they appear in the SSE are exposed in it.

Table 1. Variables in the study.

\begin{tabular}{lccc}
\hline Variables & Code & Questionnaire Items & Range \\
\hline Clmchng & D19 & $\begin{array}{c}\text { Do you think world's climate is } \\
\text { changing? }\end{array}$ & $\begin{array}{c}\text { 1: Definitely changing } \\
\text { 4: Definitely not changing }\end{array}$ \\
\hline Ccnthum & D22 & $\begin{array}{c}\text { Climate change caused by } \\
\text { natural processes, human } \\
\text { activity, or both? }\end{array}$ & $\begin{array}{c}\text { 1: Entirely by natural processes } \\
\text { 4: Mainly by human activity }\end{array}$ \\
\hline Wrclmch & D24 & How worried about climate \\
change? & $\begin{array}{c}\text { 1: Not at all worried } \\
\text { 5: Extremely worried }\end{array}$ \\
\hline Ccrdprs & D23 & $\begin{array}{c}\text { To what extent feel personal } \\
\text { responsibility to reduce climate } \\
\text { change? }\end{array}$ & 0: Not at all \\
\hline
\end{tabular}

Source: ESS.8. [29] SRC (2018).

The Spanish sample consists of 1958 valid surveys once the data has been cleaned. To carry out this work, the ages of the respondents have been grouped into four categories, have been given a numerical categorization:

(1) From 15 to 35 years (Young), with 461 members.

(2) From 36 to 50 years (Middle. aged), with 565 members.

(3) From 51 to 65 years (Mature. aged), with 528 members.

(4) From 66 to 90 years (Elderly), with 404 members.

The statistical study will be carried out in two phases:

(1) To acquire information that, in the first instance, can tell us if significant differences between the averages of the variables for the different age groups are foreseen, we proceed to calculate the basic descriptive parameters by age category (averages and standard deviation) of each dependent variable, as well as the Chi-square measures 
and the correlations between each dependent variable and the socio-demographic variable Age. With this, we already have a picture of the situation. Suppose this indicates that it is pertinent to study the relations of association between the variables with Age. In that case, we will proceed to carry out the tests of contrasting the hypotheses.

(2) If the null hypothesis is rejected, that is, if it is confirmed that the responses to the dependent variables are associated with the age of the person responding, the extent or the intensity of the reaction of an age group differs from those of the other groups will be calculated. It is done by using logistic regression to find probabilities. This method calculates how much more likely it is that an age group will give a detailed response to the items studied than the rest.

\section{Results}

\subsection{Results $1^{\circ}$ Phase}

In this section, the primary descriptors will be calculated, as well as the measures of the contrast of the hypotheses. In order to carry out this contrast, it is necessary to know in advance if the distributions of the different categories of the variables behave in a parametric or non-parametric way.

In this sense, Kolmogorov-Smirnov and Shapiro-Wilk tests are carried out, showing that distributions are non-parametric for every item analyzed. Therefore, correlations are studied by the Spearman test. However, given the high number of respondents and following the Big Numbers Law, it's possible to take the distributions as normal ones, so Pearson correlations are developed. As similar, for hypothesis contrast tests, Kruskal-Wallis is selected first, but ANOVA test -or Welch and Brown-Forsythe ones if Levene indicator confirms non-similarity of variances- are carried out too (Table 2).

Table 2. Measures for variables used in the study.

\begin{tabular}{|c|c|c|c|c|c|c|c|}
\hline & \multirow{3}{*}{ Chi-Square } & \multicolumn{4}{|c|}{$\begin{array}{c}\text { Mean } \\
\text { (Standard Desv.) }\end{array}$} & \multirow{3}{*}{ Correlations } & \multirow{3}{*}{$\begin{array}{c}\text { Contrast Tests: } \\
p \text { in K-W } \\
\text { ANOVA } \\
\text { (Welch-Forsythe) }^{a}\end{array}$} \\
\hline & & \multicolumn{4}{|c|}{ Categories } & & \\
\hline & & 1 & 2 & 3 & 4 & & \\
\hline D19 & $p<0.001$ & $\begin{array}{c}1.23 \\
(0.024)\end{array}$ & $\begin{array}{c}1.27 \\
(0.025)\end{array}$ & $\begin{array}{c}1.35 \\
(0.028)\end{array}$ & $\begin{array}{c}1.48 \\
(0.037)\end{array}$ & $\begin{array}{l}\text { Spearman: } 14.5 \% * * * \\
\text { Pearson: } 13.6 \% * * *\end{array}$ & $\begin{array}{c}\mathrm{K}-\mathrm{W}: p<0.001 \\
\text { Welch-Forsythe } p<0.001 \\
\text { (ANOVA, F:13.114) }\end{array}$ \\
\hline D22 & $p<0.001$ & $\begin{array}{c}3.57 \\
(0.029)\end{array}$ & $\begin{array}{c}3.53 \\
(0.027)\end{array}$ & $\begin{array}{c}3.41 \\
(0.032)\end{array}$ & $\begin{array}{c}3.35 \\
(0.040)\end{array}$ & $\begin{array}{l}\text { Spearman: } \\
-13.1 \%{ }^{* * *} \\
\text { Pearson: } \\
-13 . \%^{* * *}\end{array}$ & $\begin{array}{c}\text { K-W: } p<0.001 \\
\text { Welch-Forsythe } p<0.001 \\
\text { (ANOVA, F:10.270) }\end{array}$ \\
\hline D24 & $p<0.001$ & $\begin{array}{c}3.44 \\
(0.043)\end{array}$ & $\begin{array}{c}3.52 \\
(0.036)\end{array}$ & $\begin{array}{c}3.45 \\
(0.041)\end{array}$ & $\begin{array}{c}3.17 \\
(0.050)\end{array}$ & $\begin{array}{l}\text { Spearman: } \\
-9.8 \% * * * \\
\text { Pearson: } \\
-10.3 \% * * *\end{array}$ & $\begin{array}{c}\mathrm{K}-\mathrm{W}: p<0.001 \\
\text { ANOVA } p<0.001(\mathrm{~F}: 11.658)\end{array}$ \\
\hline D23 & $p<0.001$ & $\begin{array}{c}6.24 \\
(0.115)\end{array}$ & $\begin{array}{c}6.20 \\
(0.114)\end{array}$ & $\begin{array}{c}5.91 \\
(0.131)\end{array}$ & $\begin{array}{c}5.28 \\
(0.159)\end{array}$ & $\begin{array}{l}\text { Spearman: } \\
-11.6 \% * * * \\
\text { Pearson: } \\
-12.5 \% * * *\end{array}$ & $\begin{array}{l}\mathrm{K}-\mathrm{W}: p<0.001 \\
\text { Welch-Forsythe } p<0.001 \\
(\text { ANOVA, F:10.059) }\end{array}$ \\
\hline
\end{tabular}

${ }^{* * *} p<0.1 \%{ }^{a}$ : When Levene test confirms the non-similarity of variances, robustness tests (Welch and Brown-Forsythe) are used.

For all variables analyzed, hypothesis testing indicates that the statistical significance $(p)$ is less than $0.1 \%$ error. Given that it had been established in the contrast tests calculation that the maximum limit of error admitted to rejecting the null hypothesis (of no association) was $5 \%$, it is confirmed that the null hypotheses must be rejected for all the items studied. Therefore, it is corroborated that the dependent variable categories do not have similar 
averages in the groups or categories of the variable Age. Some standards differ statistically from each other, with an error of less than $5 \%$. From this point onwards, it is necessary to know which are those age categories whose averages differ statistically from each other. Thus, the so-called post-hoc tests are carried out. In order to choose which of these tests to apply, it must first be known whether there is a similarity of variances. It is done using the Levene test. If there is a similarity between the disagreements, the post-hoc test to be carried out will be the Bonferroni test, while if there is no such similarity, the Games-Howell post-hoc test will be carried out.

The Bonferroni post-hoc test is carried out for D24 (as Levene confirmed the similarity of the variances) and Games-Howell for the remaining items, as no such similarity exists. The statistically different category pairs are shown in Table 3 and graphically in Figure 1.

Table 3. Pair comparisons. Age of respondent.

\begin{tabular}{|c|c|c|c|c|c|}
\hline \multicolumn{3}{|c|}{ D19 } & \multicolumn{3}{|c|}{ D22 } \\
\hline Sample 1-Sample 2 & $\begin{array}{l}\text { Statistical } \\
\text { Desv. } \\
\text { Test }\end{array}$ & $\begin{array}{l}\text { Adjusted } \\
p^{\text {a }}\end{array}$ & Sample 1-Sample 2 & $\begin{array}{l}\text { Statistical } \\
\text { Desv. } \\
\text { Test }\end{array}$ & $\begin{array}{l}\text { Adjusted } \\
p^{\mathrm{a}}\end{array}$ \\
\hline Young-Middle aged & -0.458 & 1.000 & Elderly-Mature aged & 1.165 & 1.000 \\
\hline Young-Mature aged & -3.023 & 0.015 & Elderly-Middle aged & 3.744 & 0.001 \\
\hline Young-Elderly & -5.946 & $<0.001$ & Elderly-Young & 4.543 & $<0.001$ \\
\hline Middle aged-Mature aged & -2.707 & 0.041 & $\begin{array}{l}\text { Mature aged-- } \\
\text { Middle aged }\end{array}$ & 2.789 & 0.032 \\
\hline Middle aged-Elderly & -5.772 & $<0.001$ & Mature aged-Young & 3.687 & 0.001 \\
\hline Mature aged-Elderly & -3.252 & 0.007 & Middle aged-Young & 1.055 & 1.000 \\
\hline \multicolumn{3}{|c|}{$\begin{array}{l}\text { ANOVA }(p<0.001 ; \mathrm{F}=13.114) \\
\text { Levene: no similarity of variances: } \\
\text { Velch }(p<0.001) / \text { Forsythe }(p<0.001)\end{array}$} & \multicolumn{3}{|c|}{$\begin{array}{c}\text { ANOVA }(p<0.001 ; \mathrm{F}=10.270) \\
\text { Levene: no similarity of variances: } \\
\text { Welch }(p<0.001) / \text { Forsythe }(p<0.001)\end{array}$} \\
\hline \multicolumn{3}{|c|}{ D24 } & \multicolumn{3}{|c|}{ D23 } \\
\hline Sample 1-Sample 2 & $\begin{array}{c}\text { Statistical Des } \\
\text { Test }\end{array}$ & $\begin{array}{l}\text { Adjusted } \\
p^{\mathrm{a}}\end{array}$ & Sample 1-Sample 2 & $\begin{array}{l}\text { Statistical } \\
\text { Desv. } \\
\text { Test }\end{array}$ & $\begin{array}{l}\text { Adjusted } \\
\qquad p^{\mathrm{a}}\end{array}$ \\
\hline Elderly-Mature aged & 4.190 & $<0.001$ & Elderly-Mature aged & 3.422 & 0.004 \\
\hline Elderly-Young & 4.181 & $<0.001$ & Elderly-Middle aged & 4.678 & $<0.001$ \\
\hline Elderly-Middle aged & 5.315 & $<0.001$ & Elderly-Young & 4.744 & $<0.001$ \\
\hline Mature aged-Young & 0.069 & 1.000 & $\begin{array}{l}\text { Mature aged- } \\
\text { Middle aged }\end{array}$ & 1.295 & 1.000 \\
\hline $\begin{array}{l}\text { Mature aged- } \\
\text { Middle aged }\end{array}$ & 1.124 & 1.000 & Mature aged-Young & 1.501 & 0.800 \\
\hline Young-Middle aged & -1.029 & 1.000 & Middle aged-Young & 0.272 & 1.000 \\
\hline \multicolumn{3}{|c|}{$\begin{array}{l}\text { ANOVA }(p<0.001 ; \mathrm{F}=11.658) \\
\text { Levene: similarity variances }\end{array}$} & \multicolumn{3}{|c|}{$\begin{array}{c}\text { ANOVA }(p<0.001 ; \mathrm{F}=10.059) \\
\text { Levene: no similarity of variances: } \\
\text { Welch }(p<0.001) / \text { Forsythe }(p<0.001)\end{array}$} \\
\hline
\end{tabular}

${ }^{a}$. Significance values have been adjusted using the Bonferroni correction for various tests.

To finish this first phase, it is interesting to know if the study variables are correlated with each other and to what extent or intensity, if any (Table 4). It is verified that the bilateral correlations are highly significant, although weak, as they do not reach $50 \%$ in any case.

Once the relationships of association between items of the study and the variable Age are confirmed, we will proceed, as indicated, to approach the calculation of the probabilities of response of each one of the age groups through the binary logistic regression.

\subsection{Results $2^{\circ}$ Phase}

In the second phase of the study, the binary logistic regressions, D19, D22, and D24, have been transformed into binary dummies. The means obtained for the different age groups have been taken to choose which dummy variable. It is interesting to change each study variable to show the most remarkable differences between the age groups. With this methodology, the dummies used in Table 5 are the result of doing: 
- Dummy 19: value 1 for D19 $=1$, rest of values $=0$.

- Dummy 22: value 4 for D22 $=1$, rest of values $=0$.

- Dummy 24: value 5 for D24 $=1$, rest of values $=0$.

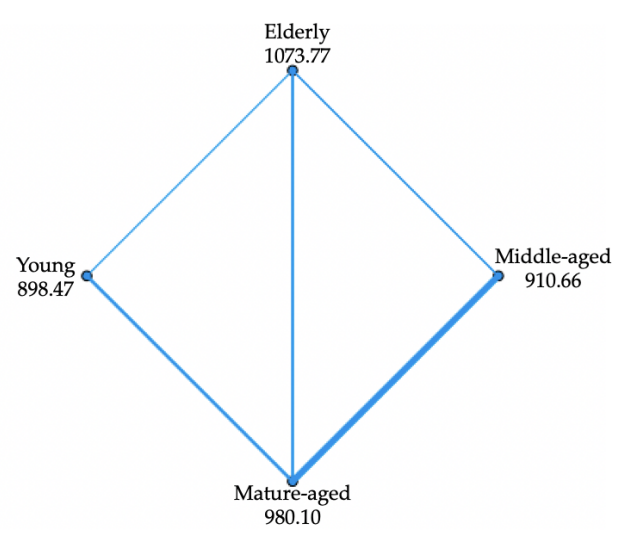

(a)

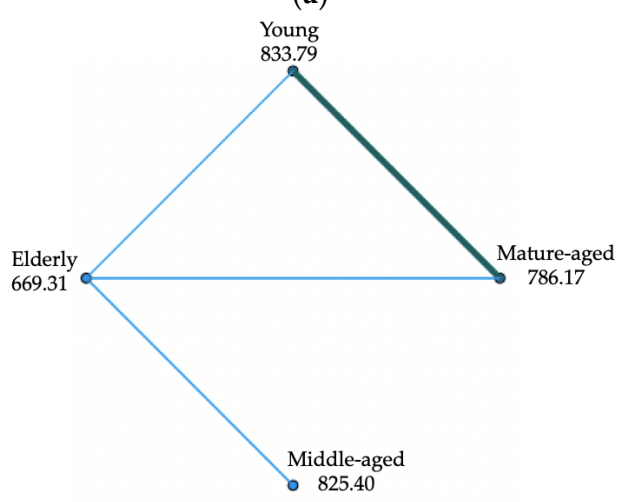

(c)

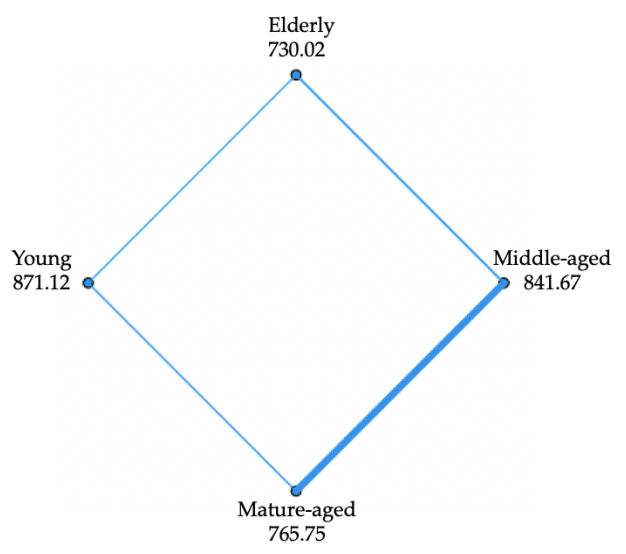

(b)

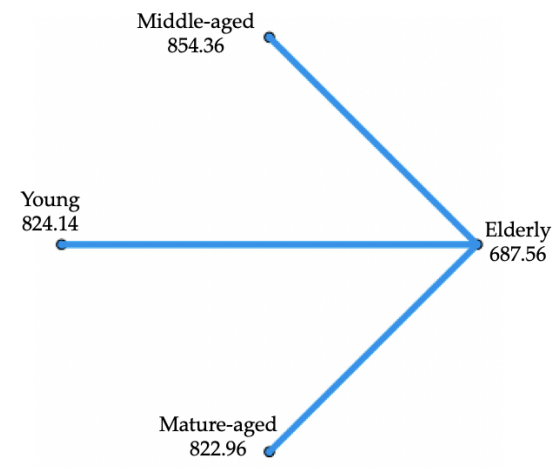

(d)

Figure 1. Pair comparisons. Categories of age of respondent: (a) D19: Do you think world's climate is changing; (b) D22: Climate change caused by natural processes, human activity, or both? (c) D23: To what extent feel a personal responsibility to reduce climate change? (d) D24: How worried about climate change? All relations contrast tests with significance $p<0.1 \%$.

Table 4. Correlations between studied variables.

\begin{tabular}{ccccc}
\hline Variables & & D22 & D24 & D23 \\
\hline \multirow{2}{*}{ D19 } & Spearman & $-0.198^{* *}$ & $-0.317^{* *}$ & $-0.191^{* *}$ \\
\cline { 2 - 5 } & Pearson & $-0.210^{* *}$ & $-0.304^{* *}$ & $-0.187^{* *}$ \\
\hline \multirow{2}{*}{ D22 } & Spearman & & $0.248^{* *}$ & $0.165^{* *}$ \\
\cline { 2 - 5 } & Pearson & & $0.270^{* *}$ & $0.179^{* *}$ \\
\hline D23 & Spearman & & $0.478^{* *}$ & \\
\hline$* 1 \%$. & & &
\end{tabular}

Having already obtained the binary variables (1.0) for each item, the ODD ratios have been calculated. An ODD ratio can be defined as the probability of an event or phenomenon occurring versus the possibility of not happening. It measures, at the same time, the strength of the relationship between two variables. In logistic regression, this measure is represented by $\operatorname{Exp}(B)$ and reflects the respective probabilities' intensity. The statistical significance and the corresponding confidence interval are also calculated to confirm the relationship. It should be noted that, since for the averages of each variable, have been found that elderly group shows either minimum or maximum values, depending 
on the item, group 4 is taken as the reference group when establishing probability measures. Therefore, the $\operatorname{Exp}(B)$ shown in Tables 5 and 6 reflect how likely a respondent in the age group indicated in brackets will answer 1 in the respective dummy variable versus not answering 1 with the same ratio in age group 4.

Table 5. Parameters for the relationship between items and age of respondent (age category of reference: 4).

\begin{tabular}{|c|c|c|c|c|c|c|c|c|c|c|c|c|}
\hline \multirow{3}{*}{$\begin{array}{c}\text { Variable } \\
\text { Age of } \\
\text { Respondent }\end{array}$} & \multicolumn{4}{|c|}{ Dummy 19} & \multicolumn{4}{|c|}{ Dummy 22} & \multicolumn{4}{|c|}{ Dummy 24} \\
\hline & \multirow[t]{2}{*}{ Sig. } & \multirow[t]{2}{*}{$\begin{array}{l}\text { Exp } \\
\text { (B) }\end{array}$} & \multicolumn{2}{|c|}{$\begin{array}{l}95 \% \text { C.I. } \\
\operatorname{EXP(B)~}{ }^{a}\end{array}$} & \multirow[t]{2}{*}{ Sig. } & \multirow{2}{*}{$\begin{array}{l}\text { Exp } \\
\text { (B) }\end{array}$} & \multicolumn{2}{|c|}{$\begin{array}{l}95 \% \text { C.I. } \\
\text { EXP(B) }^{\text {a }}\end{array}$} & \multirow[t]{2}{*}{ Sig. } & \multirow[t]{2}{*}{$\begin{array}{l}\text { Exp } \\
\text { (B) }\end{array}$} & \multicolumn{2}{|c|}{$\begin{array}{l}95 \% \text { C.I. } \\
\operatorname{EXP(B)~}{ }^{a}\end{array}$} \\
\hline & & & Inf. & Sup. & & & Inf. & Sup. & & & Inf. & Sup. \\
\hline Age & $<0.001$ & & & & $<0.001$ & & & & 0.068 & & & \\
\hline Age (1) & $<0.001$ & 2.448 & 1.797 & 3.336 & $<0.001$ & 1.921 & 1.422 & 2.596 & 0.026 & 2.318 & 1.108 & 4.848 \\
\hline Age (2) & $<0.001$ & 2.303 & 1.721 & 3.082 & 0.001 & 1.653 & 1.240 & 2.202 & 0.010 & 2.548 & 1.248 & 5.202 \\
\hline Age (3) & 0.003 & 1.538 & 1.160 & 2.041 & 0.308 & 1.164 & 0.869 & 1.560 & 0.015 & 2.455 & 1.188 & 5.072 \\
\hline Constant & $<0.001$ & 1.634 & & & 0.080 & 0.820 & & & $<0.001$ & 0.033 & & \\
\hline
\end{tabular}

Table 6. Parameters for a relationship between item D23 and age of respondent (age category of reference: 4).

\begin{tabular}{|c|c|c|c|c|c|c|c|c|}
\hline \multirow{3}{*}{$\begin{array}{c}\text { Variable } \\
\text { Age of Respondent }\end{array}$} & \multicolumn{4}{|c|}{ Dummy 23A } & \multicolumn{4}{|c|}{ Dummy 23B } \\
\hline & \multirow[t]{2}{*}{ Sig. } & \multirow[t]{2}{*}{$\operatorname{Exp}(B)$} & \multicolumn{2}{|c|}{$\begin{array}{l}95 \% \text { C.I. } \\
\operatorname{EXP(B)~}\end{array}$} & \multirow[t]{2}{*}{ Sig. } & \multirow[t]{2}{*}{$\operatorname{Exp}(B)$} & \multicolumn{2}{|c|}{$\begin{array}{l}95 \% \text { C.I. } \\
\text { EXP(B) }\end{array}$} \\
\hline & & & Inf. & Sup. & & & Inf. & Sup. \\
\hline Age & 0.041 & & & & $<0.001$ & & & \\
\hline Age (1) & 0.026 & 1.481 & 1.049 & 2.090 & $<0.001$ & 1.908 & 1.401 & 2.600 \\
\hline Age (2) & 0.005 & 1.607 & 1.154 & 2.238 & $<0.001$ & 1.887 & 1.401 & 2.542 \\
\hline Age (3) & 0.039 & 1.432 & 1.019 & 2.013 & $<0.001$ & 1.702 & 1.255 & 2.308 \\
\hline Constant & $<0.001$ & 0.301 & & & $<0.001$ & 0.560 & & \\
\hline
\end{tabular}

a: When statistical significance is given at the level of error $<5 \%$, confidentiality intervals do not contain the unit.

For item D23, two possibilities have been studied, with the dummies variables:

- $\quad$ Dummy 23A: value from 8 to $10=1$ and from 0 to $7=0$.

- Dummy 23B: value from 7 to $10=1$ and from 0 to $6=0$.

Just as we worked with the dummies of items D19, D22, and D24, in this case, ODDs ratios, statistical significance, and confidence intervals are calculated (Table 6).

\section{Discussion}

\subsection{1st Phase Discussion}

Taking into account the means and correlations obtained in Table 1, the first reflections that can be made are the following:

(1) For the variable D19: The averages for all age groups are less than 2. It is concluded that all respondents, regardless of age group, seem to think that the global climate is changing. The correlations of both Spearman and Pearson are positive, with an error of less than $0.1 \%$. In other words, the older the person, the higher the value given to this item. Therefore, the less they believe in this change.

(2) In variable D22, all the averages of the age groups are more significant than 3, so all groups think that climate change is being caused more by human activity than by natural issues. The correlations are negative, with an error of less than $0.1 \%$ : in other words, the older the age, the fewer people think that it is due to human causes.

(3) All four age groups value the issue represented by the variable D24 with an average above 3 , so it can say that they are all concerned about climate change. The correlations 
are harmful and also with an error of less than $0.1 \%$. Therefore, it seems that the older they are, the less concern they show.

(4) Consistent with the views in D22 and D24, all age groups have averages above 5 for variable D23. That is, they feel a responsibility to reduce climate change. The correlations are harmful and have an error rate of less than $0.1 \%$. Consequently, it seems that the older the age, the less awareness there is in this regard.

For the four items, the Chi-square test shows a clear significance with the variable Age, as $p$ is less than $0.1 \%$. The highest correlations are around $14 \%$, correspond to items D19, D22, and are a little lower in D23 (approximately 13\%) and D24 (around 10\%) and show to be significant at the level of $0.1 \%$. Consequently, the results in this first step of phase 1 seem to suggest that there will be an association between items and the age of the respondent.

After performing the contrast tests, K-W, ANOVA, and the robustness tests if needed, it can be seen that the four questions are associated with the age of the respondents, as in all statistical significance is intense $(p<0.1 \%)$. In three, D19, D22, D23, a clear difference between the extreme generations is evident. The most significant statistical differences in the means are between the young and the old, all at a level of $0.1 \%$ error (Table 3 and Figure 1). Young people are the most supportive of the fact that the climate is changing, that it is caused by human activity, and that they feel a greater responsibility for reducing climate change [34,35]. In D24, the middle-aged respondents (up to 50 years old) make the most significant difference relative to older respondents. The middle-aged respondents are the most concerned about climate change.

As discussed in the Introduction section, it seems logical to think that if a person is concerned about the effects of climate change, they will be willing to do their part to reduce them, and the greater the concern, the greater the willingness. Table 4 shows the correlations between the items studied. All are significant at $0.1 \%$ but weak. However, the highest correlations are found among the items representing both issues, that is, between D24 and D23.

\subsection{Discussion $2^{\circ}$ Phase}

Given that the association relations are confirmed, and that these present vital statistical significances, once the variables have been transformed into those of a binary type (dummies) that are of interest to study, according to the results of the averages in each age group, the probabilities of responses of each group are calculated taking as a reference that of the oldest group, as already explained in the section on Results. Following the data found through logistic regression, which are reflected in Tables 5 and 6, the following conclusions are reached:

(1) The variable D19: If a young person is asked, he is 2.448 times more likely to respond that the climate is changing than when an older person is asked. These probabilities drop to 2.303 times and to 1.538 times if a middle-aged person or an older person is asked, respectively, about an older person. All associations have a significance of less than $0.1 \%$.

(2) For the variable D22: If a young person is asked, she is 1.921 times more likely to respond that climate change is primarily due to human action (value 4 in the item) than when asked an older person. This probability drops to 1.653 times if a middleaged person is asked about an older person. Both with a significance of less than $0.1 \%$. In the case of mature people, no statistical significance is given $(p>5 \%)$; it means that there is no statistical difference between the average from group 3 and group 4 for the approach made with the variable dummy of D22.

(3) The variable D24: If a middle-aged person is asked, there are 2.548 times more likely to respond that they are apprehensive about climate change (value 5 of the item) than when an older person is asked, and 2.318 times if a young person is asked about an older person. Both with a significance of less than $5 \%$. 
(4) For the variable D23, a double study has been carried out, which leads to the conclusion that:

- $\quad$ D23A: If asked, a middle-aged person is 1.607 times more likely to respond that they feel very too highly responsible for reducing climate change (values of 8 to 10 in the item) than when asked an older person (error $<1 \%$ ). This probability drops to 1.481 times if a young person is asked (error $<5 \%$ ), and to 1.432 times if a middle-aged person is asked (error $<5 \%$ ).

- D23B: If a young person is asked, there is 1.908 times more probability that he or she will respond that he or she feels entirely responsible to highly responsible (values of 7 to 10 in the item) for reducing climate change than when an older person is asked (error $<0.1 \%$ ). This probability decreases to 1.887 times if a middle-aged person is asked and 1.702 times if a middle-aged person is asked (all by error $<1 \%$ ).

\section{Conclusions}

In line with the theoretical framework of this research, the sample analyzed shows clear and intense relationships (with errors less than $0.1 \%$ for all associations) between be-longing to younger or older ages when it comes to showing greater or lesser awareness, respectively, that the world's climate is changing. Consequently, this brings about a respective greater or lesser readiness towards the Green Economy and actions that reduce climate change.

Hypotheses H1 (Younger people are more aware of climate change), H2 (Younger people are more aware that climate change is caused by human action), and H4 (Younger people take more responsibility for reducing climate change) are fulfilled. The H3 hypothesis (youngest are the most concerned about the effects of climate change) is fulfilled, although not for the youngest but for the middle-aged, between 36 and 50 years old.

This research's findings lead us to two main conclusions and implications, theoretical and applied, as contributions. The first is that, in reality, for questions about whether the climate is changing, or whether it is believed to be due to human causes or, on the other hand, natural causes, and whether this is a concern. The differences show that, in general, the younger people are more aware of climate change, but, especially, the older people are less aware concerning any other age group. The second is that, as a result, the leaders, whether they are the governors, or competent authorities in the macroeconomic scenario, or the managers, or heads in the microeconomic scenario of the company, should consider promoting, designing, implementing, and evaluating initiatives that encourage awareness of the issue of climate change. Not only for the new generations, but for the general population, for all age groups, but with particular attention to the elderly. As noted, this research highlights the environmental perceptions of different generations of citizens in Spain regarding climate change in the digital society. Unlike other recent studies, this article's attraction or novelty lies in the fact that this empirical analysis is carried out from the perspectives of awareness, human action, and self-responsibility [61,62]. Perhaps, this phenomenon -the difficulty of reaching the different generations with the same initiatives from this perspective-, together with other reasons of an eco-political nature, hinders the implementation of new models of governance based on sustainable development, green economy, and social happiness by the top management of public administrations [63]. All these factors constitute relevant axial pieces that politicians have at their disposal to cultivate productive ecosystems in symbiosis with ecology, renewable energies, and sustainability [64]. It is undoubtedly an approach that we consider effective in the fight against climate change and can raise awareness among future, and present, generations that a green planet is synonymous with well-being, health, and quality of life [65].

Notwithstanding the above, this work is not without its limitations. The first refers to the study's characteristics: the selection of the population sample by the multi-stage sampling method. This circumstance makes it difficult to avoid possible statistical biases that may have originated in our analysis. The second is because this work is transversal 
and not longitudinal, hence developing extended research in the future. The third refers to the fact that the analysis is carried out on Spain's population; it would complement this study to carry out similar investigations for other countries.

On the other hand, the data from the last survey carried out by EUROSTAT on climate issues, with which we have worked, is from 2018. The questions have been selected from a longer list. Having all of them could have given us a more detailed picture. However, their complete analysis would have substantially exceeded the dimensions of this paper. Hence, those considered to be the main issues for this first portrait of Spanish society about climate change before the health crisis caused by COVID-19 have been selected.

To continue with this line of work, it would be advisable, on the one hand, to analyze the evolution of opinion in the Spanish population on these issues, especially in the postpandemic era, periodically making this type of consultation on climate change and the predisposition to try to reduce it. It is necessary to point out that the arrival of the SARSCoV2 virus has brought about essential changes in individuals' perception of human action's role in nature. Precisely, this pandemic has come at a time characterized, among other things, by a slowdown in public policies that contribute to the implementation of the energy transition in the globalized world. In this sense, it would be advisable to carry out a transnational and comparative study, as we mentioned, analyzing these same items in a post-pandemic scenario in order to find out the opinion-and changes, if any-of Spanish societies, other European countries and third countries in this respect, as well as the reactions that could be expected from them in favor of reducing the effects of business and human activity on climate change $[66,67]$.

This public awareness can serve to cultivate an ecosystem based on the guiding principles of sustainability, the environment, ecology and happiness management [68], given the existence of macroeconomic policies quite far removed from the Paris agreements and the 2030 Agenda [16]. In light of what has been argued and aware of a wide range of grays, we consider that citizens' happiness must become an attractive intangible resource that promotes the territories' green and sustainable economic growth [69]. The happinessenvironment relationship can exponentially combat myopia caused by having productive tissues that lack large energy infrastructures [70].

By way of conclusion, it should note that this article was born to draw a theoreticalpractical framework of reference that frames the Green Economy as a prism of opportunities to build governance strategies based on sustainable, ecological, solidarity growth, etc. To draw this roadmap, citizens' happiness must be the differential strategic factor that drives citizens' collective well-being as the engine to make a better and eco-sustainable world [71].

Author Contributions: Conceptualization, M.-J.F.-R., R.R.-R. and J.A.L.-S.; methodology, M.-J.F.-R. and R.R.-R.; software, M.-J.F.-R.; validation, M.-J.F.-R. and R.R.-R.; formal analysis, M.-J.F.-R. and R.R.-R.; investigation, M.-J.F.-R., R.R.-R. and J.A.L.-S.; resources, M.-J.F.-R., R.R.-R. and J.A.L.-S.; data curation, M.-J.F.-R.; writing-original draft preparation, M.-J.F.-R., R.R.-R. and J.A.L.-S.; writingreview and editing, M.-J.F.-R., R.R.-R. and J.A.L.-S.; visualization, M.-J.F.-R., R.R.-R. and J.A.L.-S.; supervision, M.-J.F.-R. and R.R.-R.; project administration, M.-J.F.-R., R.R.-R. and J.A.L.-S.; funding acquisition, INDESS. All authors have read and agreed to the published version of the manuscript.

Funding: This publication and research have been (totally/partially) granted by INDESS (Research Universitary Institute for Sustainable Social Development), Universidad de Cádiz, Spain.

Institutional Review Board Statement: Not applicable.

Informed Consent Statement: Not applicable.

Data Availability Statement: As indicated, the survey with which we have worked is the European Social Survey (ESS), Round 8, available at https:/ / www.europeansocialsurvey.org/data/download. html? $\mathrm{r}=8$.

Conflicts of Interest: The authors declare no conflict of interest. The funders had no role in the design of the study; in the collection, analyses, or interpretation of data; in the writing of the manuscript; or in the decision to publish the results. 


\section{References}

1. Cosgrove, B. La Atmosfera y el Tiempo; Biblioteca Visual Altea: Mexico City, Mexico, 1994; p. 18.

2. Garduño, R. ¿Qué es el Efecto Invernadero? Cambio Climático: Una Visión Desde México. 2004. Available online: https://www. iies.unam.mx/wp-content/uploads/2016/03/Victor-Jaramillo-Cambio-Climatico-Una-Vision-desde-Mexico-.pdf\#page=27 (accessed on 28 November 2020).

3. Rivera, M.A. El Cambio Climático. Consejo Nacional para la Cultura y las Artes, México. 1999. Available online: https:/ / scholar.google.es/scholar?hl=es\&as_sdt=0\%2C5\&q=-\%09Rivera\%2C+M.A.+\%281999\%29.+El+cambio+clim\%C3 $\%$ A1tico.+Consejo+Nacional+para+la+Cultura+y+las+Artes\%2C+M\%C3\%A9xico.+\&btnG= (accessed on 28 November 2020).

4. Voituriez, B. La Atmósfera y el Clima; RBA Editores: Barcelona, Spain, 1994.

5. Climático, Sobre el Cambio. Convención Marco de las Naciones Unidas Sobre el Cambio Climático. 1992. Available online: https:/ / unfccc.int/resource/docs/convkp/convsp.pdf (accessed on 20 January 2021).

6. Munich Re. Topics Geo. Natural Catastrophes 2015 Analyses, Assessments, Positions 2016 Issue. MünchenerRückversicherungs Gesellschaft, Munich, Germany. 2016. Available online: https://www.munichre.com/site/touch-publications/get/documents_ E1273659874/mr/assetpool.shared/Documents/5_Touch/_Publications/302-08875_en.pdf (accessed on 20 January 2021).

7. Climate change. In The Physical Sciencie Basis, 3rd ed.; IPCC: Geneva, Switzerland, 2013; Available online: https:/ / archive.ipcc. ch/report/ar5/wg1/index_es.shtml (accessed on 20 January 2021).

8. Salvador, A.G.; Alcaide, A.S.; Sánchez, C.C.; Salvador, L.G. Evaluación de Impacto Ambiental. Madrid. 2005. Available online: https:/ /www.auditorlider.com/wp-content/uploads/2019/07/Evaluacion-impacto-ambiental-Garmendia-PDF-1.pdf (accessed on 20 January 2021).

9. Steffen, W.; Persson, A.; Deutsch, L.; Zalasiewicz, J.; Williams, M.; Richardson, K.; Crumley, C.; Crutzen, P.; Folke, C.; Gordon, L.; et al. The anthropocene: From global change to planetary stewardship. Ambio 2011, 40, 739-761. [CrossRef] [PubMed]

10. Rokeach, M. The Nature of Human Values; Free Press: New York, NY, USA, 1973.

11. AR5 Synthesis Report. Climate Change 2014; IPCC: Geneva, Switzerland, 2014.

12. Climate Change: What It Means for Us, Our Children, and Our Grandchildren; Dimento, J.F.C.; Doughman, P.; Levesque, S. (Eds.) MIT Press: Cambridge, MA, USA, 2014. Available online: https://books.google.es/books?hl=es\&lr=\&id= 3YMUAwAAQBAJ\&oi=fnd\&pg=PR5\&dq=DiMento,+Joseph+F.+C.\%3B+Doughman, +Pamela+M.+(2007).+Climate+Change: +What+It+Means+for+Us, +Our+Children,+and+Our+Grandchildren+(en+ingl\%C3\%A9s) (accessed on 20 January 2021).

13. Clark, P.U.; Shakun, J.D.; Marcott, S.A.; Mix, A.C.; Eby, M.; Kulp, S.; Levermann, A.; Milne, G.A.; Pfister, P.L.; Santer, B.D.; et al. Consequences of twenty-first-century policy for multi-millennial climate and sea-level change. Nat. Clim. Chang. 2016, 6, 360-369. [CrossRef]

14. Intergovernmental Panel on Climate Change. Climate change 2007. In The Physical Science Basis: Summary for Policymakers; IPCC: Geneva, Switzerland, 2007. Available online: https://previa.uclm.es/area/amf/antoine/energias/Ipcc_anotado.pdf (accessed on 28 November 2020).

15. Intergovernmental Panel on Climate Change. Climate Change 2007: The Physical Science Basis. 2007. Available online: http:/ / users.telenet.be/j.janssens / CommentsSPM4web.pdf (accessed on 28 November 2020).

16. Naciones Unidas. Informe de los Objetivos de Desarrollo Sostenible 2019; Publicación de las Naciones Unidas, Dpto. de Asuntos Económicos y Sociales: New York, NY, USA, 2019. Available online: https://unstats.un.org/sdgs/report/2019/The-SustainableDevelopment-Goals-Report-2019_Spanish.pdf (accessed on 31 December 2020).

17. United Nations. Objetivos de Desarrollo del Milenio. 2005. Available online: http://millenniumindicators.un.org/unsd/mi/ pdf/MDG\%20BOOK_SP_new.pdf (accessed on 28 November 2020).

18. Warren, R.; Hope, C.; Mastrandrea, M.; Tol, R.; Adger, N.; Lorenzoni, I. Spotlighting Impacts Functions in Integrated Assessment. Tyndall Centre on Climate Change Research. 2006. Available online: https://www.researchgate.net/profile/Richard_Tol2 /publication/221678858_Spotlighting_Impacts_Functions_in_Integrated_Assessment_Models/links/0912f50d44f0f50ae10000 00/Spotlighting-Impacts-Functions-in-Integrated-Assessment-Models.pdf (accessed on 28 November 2020).

19. Hitz, S.; Smith, J. Estimating global impacts from climate change. Glob. Environ. Chang. 2004, 14, 201-218. [CrossRef]

20. Arnell, N.W. Climate change and global water resources: SRES emissions and socio-economic scenarios. Glob. Environ. Chang. 2004, 14, 31-52. [CrossRef]

21. Nicholls, R.J. Coastal flooding and wetland loss in the 21st century: Changes under the SRES climate and socio-economic scenarios. Glob. Environ. Chang. 2004, 14, 69-86. [CrossRef]

22. Arnell, N.W.; Cannell, M.G.R.; Hulme, M.; Kovats, R.S.; Mitchell, J.F.B.; Nicholls, R.J.; Parry, M.L.; Livermore, M.T.J.; White, A. The Consequences of CO2 Stabilisation for the Impacts of Climate Change. Clim. Chang. 2002, 53, 413-446. [CrossRef]

23. Parry, M.L.; Rosenzweig, C.; Iglesias, A.; Livermore, M.; Fischer, G. Effects of climate change on global food production under SRES emissions and socio-economic scenarios. Glob. Environ. Chang. 2004, 14, 53-67. Available online: https:/ / www.sciencedirect. com/science/article/abs/pii/S0959378003000827 (accessed on 28 November 2020). [CrossRef]

24. Van Lieshout, M.; Kovats, R.; Livermore, M.; Martens, P. Climate change and malaria: Analysis of the SRES climate and socio-economic scenarios. Glob. Environ. Chang. 2004, 14, 87-99. [CrossRef]

25. Arnell, N.W.; Lowe, J.A.; Brown, S.; Gosling, S.N.; Gottschalk, P.; Hinkel, J.; Lloyd-Hughes, B.; Nicholls, R.J.; Osborn, T.J.; Osborne, T.M.; et al. A global assessment of the effects of climate policy on the impacts of climate change. Nat. Clim. Chang. 2013, 3, 512-519. [CrossRef] 
26. Harrison, P.A.; Holman, I.P.; Cojocaru, G.; Kok, K.; Kontogianni, A.; Metzger, M.J.; Gramberger, M. Combining qualitative and quantitative understanding for exploring cross-sectoral climate change impacts, adaptation and vulnerability in Europe. Reg. Environ. Chang. 2012, 13, 761-780. [CrossRef]

27. Metzger, M.J.; Leemans, R.; Schröter, D. A multidisciplinary multi-scale framework for assessing vulnerabilities to global change. Int. J. Appl. Earth Obs. Geoinf. 2005, 7, 253-267. [CrossRef]

28. Piontek, F.; Müller, C.; Pugh, T.A.M.; Clark, D.B.; Deryng, D.; Elliott, J.; González, F.D.; Flörke, M.; Folberth, C.; Franssen, W.; et al. Multisectoral climate impact hotspots in a warming world. Proc. Natl. Acad. Sci. USA 2014, 111, 3233-3238. [CrossRef] [PubMed]

29. Schewe, J.; Heinke, J.; Gerten, D.; Haddeland, I.; Arnell, N.W.; Clark, D.B.; Dankers, R.; Eisner, S.; Fekete, B.M.; Colón-González, F.J.; et al. Multimodel assessment of water scarcity under climate change. Proc. Natl. Acad. Sci. USA 2014, 111, 3245-3250. [CrossRef] [PubMed]

30. Warszawski, L.; Frieler, K.; Huber, V.; Piontek, F.; Serdeczny, O.; Schewe, J. The Inter-Sectoral Impact Model Intercomparison Project (ISI-MIP): Project framework. Proc. Natl. Acad. Sci. USA 2014, 111, 3228-3232. [CrossRef] [PubMed]

31. Crate, S.A. Gone the bull of winter? Contemplating climate change's cultural implications in northeastern Siberia, Russia. In Anthropology and Climate Change: From Encounters to Actions; Routledge: Abingdon, UK, 2009; pp. 139-152.

32. Cassidy, R. Lives With Others: Climate Change and Human-Animal Relations. Annu. Rev. Anthr. 2012, 41, 21-36. [CrossRef]

33. Brasil. Decreto-Lei $n^{\circ} 227$, de 28 de Fevereiro de 1967. Dá Nova Redação ao Decreto-lei ${ }^{\circ} 1.985$, de 29 de Janeiro de 1940 (Código de Minas). 1967. Available online: http:/ / www.planalto.gov.br/ccivil_03/Decreto-Lei/Del0227.htm (accessed on 19 October 2020).

34. Sejersen, F. Copenhagen: Royal Danish Academy of Sciences and letters. The Question of Resilience: Social Responses to Climate Change. In Resilience, Human Agency, and Climate Change Adaptation Strategies in the Arctic; Hastrup, K., Ed.; 2009; pp. $218-244$. Available online: https:/ / research.ku.dk/search/result/?pure=en/publications/resilience-human-agency-and-climate-changeadaptation-strategies-in-the-arctic (accessed on 20 January 2021).

35. Tsosie, R. Indigenous People and Environmental Justice: The Impact of Climate Change; University of Colorado: Boulder, CO, USA, 2007; Volume 78, pp. 1625-1677. Available online: https://heinonline.org/HOL/LandingPage?handle=hein.journals/ucollr78\& div $=53 \&$ id $=\&$ page $=($ accessed on 20 January 2021) .

36. Moser, S.C.; Dilling, L. Communicating Climate Change: Closing the Science-Action Gap. In The Oxford Handbook of Climate Change and Society; Oxford University Press: Oxford, UK, 2011; pp. 161-174. Available online: https: //books.google.es/books?hl=es\&lr=\&id=RsYr_iQUs6QC\&oi=fnd\&pg=PA161\&ots=r7KJ86sd_G\&sig=XzIjef_A5BrrrwNp6o7f2 d0rCNM\&redir_esc=y\#v=onepage\&q\&f=false (accessed on 31 December 2020).

37. Steffen, W.; Richardson, K.; Rockström, J.; Cornell, S.E.; Fetzer, I. Planetary Boundaries: Guiding human development on a changing planet. Science 2015, 347, 6223. Available online: https:/ / science.sciencemag.org/content/347/6223/1259855.abstract (accessed on 31 December 2020). [CrossRef]

38. Gentina, E.; Muratore, I. Environmentalism at home: The process of ecological resocialization by teenagers. J. Consum. Behav. 2012, 11, 162-169. [CrossRef]

39. Grønhøj, A. Communication about consumption: A family process perspective on 'green' consumer practices. J. Consum. Behav. 2006, 5, 491-503. [CrossRef]

40. Leppänen, J.M.; Haahla, A.E.; Lensu, A.M.; Kuitunen, M.T. Parent-Child Similarity in Environmental Attitudes: A Pairwise Comparison. J. Environ. Educ. 2012, 43, 162-176. [CrossRef]

41. Li, J.; Liu, C. Intergenerational influence on adolescents' proenvironmental behavior. Soc. Behav. Pers. 2016, 44, 589-601. Available online: https:/ / scholar.google.com/scholar?q=Intergenerational $\% 20$ influence $\% 20$ on $\% 20$ adolescents $\% 20$ pro-environmental\% 20behavior (accessed on 31 December 2020). [CrossRef]

42. Phoenix, A.; Boddy, J. Environment in the Lives of Children and Families: Perspectives from India and the UK; Policy Press: Bristol, UK, 2017. Available online: https:/ / scholar.google.com/scholar_lookup?title=Environment $\% 20$ in $\% 20$ the $\% 201$ ives $\% 20$ of $\% 20$ children $\% 20$ and $\% 20$ families $\% 3 \mathrm{~A} \% 20$ Perspectives $\% 20$ from $\% 20$ India $\% 20$ and $\% 20$ the $\% 20$ UK\&publication_year=2017\&author= A.\%20Phoenix\&author=J.\%20Boddy\&author=C.\%20Walker\&author=U.\%20Vennam (accessed on 31 December 2020).

43. Ferrara, R. The Smart City and the Green Economy in Europe: A Critical Approach. Energies 2015, 8, 4724-4734. [CrossRef]

44. Ravina-Ripoll, R.; Tobar-Pesantez, L.; Núñez-Barriopedro, E.; Galiano-Coronil, A. (Eds.) La Brújula del Siglo XXI: El Happiness Management; Tirant Lo Blanc: Valencia, Spain, 2020.

45. Corner, A.; Roberts, O.; Chiari, S.; Völler, S.; Mayrhuber, E.S.; Mandl, S.; Monson, K. How do young people engage with climate change? The role of knowledge, values, message framing, and trusted communicators. Wiley Interdiscip. Rev. Clim. Chang. 2015, 6, 523-534. [CrossRef]

46. Ojala, M.; Lakew, Y. Young People and Climate Change Communication. In Oxford Research Encyclopedia of Climate Science; Oxford University Press (OUP): Oxford, UK, 2017.

47. Zaval, L.; Cornwell, J.F.M. Effective education and communication strategies to promote environmental engagement. Eur. J. Educ. 2017, 52, 477-486. [CrossRef]

48. Ojala, M. Climate change skepticism among adolescents. J. Youth Stud. 2015, 18, 1135-1153. [CrossRef]

49. Gifford, R.; Scannell, L.; Kormos, C.E.; Smolova, L.; Biel, A.; Boncu, S.; Corral, V.; Güntherf, H.; Hanyu, K.; Hine, D.; et al. Temporal pessimism and spatial optimism in environmental assessments: An 18-nation study. J. Environ. Psychol. 2009, $29,1-12$. [CrossRef] 
50. Hendrickx, L.; Nicolaij, S. Temporal discounting and environmental risks: The role of ethical and loss-related concerns. J. Environ. Psychol. 2004, 24, 409-422. [CrossRef]

51. ESS Interviewer Briefing: NC Manual: European Social Survey; ERIC: London, UK, 2018.

52. Francés, F.J.; Alaminos, A.; Penalva, C.; Santacreu, O.A. El Proceso de Medición de la Realidad Social: La Investigación a Través de Encuestas; PYDLOS Ediciones: Cuenca, Ecuador, 2014.

53. Poortinga, W.; Fisher, S.; Böhm, G.; Steg, L.; Whitmarsh, L. Actitudes ante el Cambio Climático y la Energía en Europa: Principales Resultados de la Octava Edición de la Encuesta Social Europea; ESS ERIC: London, UK, 2018.

54. Verschoor, M.; Albers, C.; Poortinga, W.; Böhm, G.; Steg, L. Exploring relationships between climate change beliefs and energy preferences: A network analysis of the European Social Survey. J. Environ. Psychol. 2020, 70, 101435. [CrossRef]

55. McGonagle, A. Common method variance. In The SAGE Encylopedia of Industrial and Organizational Psychology; Rogelberg, S., Ed.; SAGE: Thousand Oaks, CA, USA, 2017; pp. 191-194.

56. Malhotra, N.K.; Schaller, T.K.; Patil, A. Common Method Variance in Advertising Research: When to Be Concerned and How to Control for It. J. Advert. 2016, 46, 193-212. [CrossRef]

57. Gómez-Román, C.; Lima, M.L.; Seoane, G.; Sabucedo, J.-M.; Dono, M.; Sabucedo, J.-M. Testing Common Knowledge: Are Northern Europeans and Millennials more Concerned about the Environment? Sustainability 2020, 13, 45. [CrossRef]

58. Dias, N.M.O.C.; Vidal, D.G.; Sousa, H.F.P.E.; Dinis, M.A.P.; Leite, Â. Exploring Associations between Attitudes Towards Climate Change and Motivational Human Values. Climate 2020, 8, 135. [CrossRef]

59. Rubio-Valverde, J.R.; Nusselder, W.J.; MacKenbach, J.P. Educational inequalities in Global Activity Limitation Indicator disability in 28 European Countries: Does the choice of survey matter? Int. J. Public Health 2019, 64, 461-474. [CrossRef] [PubMed]

60. Ayalon, L.; Doron, I.; Bodner, E.; Inbar, N. Macro- and micro-level predictors of age categorization: Results from the European Social Survey. Eur. J. Ageing 2013, 11, 5-18. [CrossRef] [PubMed]

61. Thew, H.; Middlemiss, L.; Paavola, J. Does youth participation increase the democratic legitimacy of UNFCCC-orchestrated global climate change governance? Environ. Politics 2021, 1-22. [CrossRef]

62. Kuthe, A.; Keller, L.; Körfgen, A.; Stötter, H.; Oberrauch, A.; Höferl, K.-M. How many young generations are there?-A typology of teenagers' climate change awareness in Germany and Austria. J. Environ. Educ. 2019, 50, 172-182. [CrossRef]

63. Sikora, A. European Green Deal-Legal and financial challenges of the climate change. ERA Forum 2021, 21, 681-697. [CrossRef]

64. Sokka, L.; Pakarinen, S.; Melanen, M. Industrial symbiosis contributing to more sustainable energy use-An example from the forest industry in Kymenlaakso, Finland. J. Clean. Prod. 2011, 19, 285-293. [CrossRef]

65. Poland, B.; Dooris, M. A green and healthy future: The settings approach to building health, equity and sustainability. Crit. Public Health 2010, 20, 281-298. [CrossRef]

66. Yergin, D. The New Map: Energy, Climate, and the Clash of Nations; Penguin Press: New York, NY, USA, 2020.

67. Lyeonov, S.; Pimonenko, T.; Bilan, Y.; Štreimikienè, D.; Mentel, G. Assessment of Green Investments' Impact on Sustainable Development: Linking Gross Domestic Product Per Capita, Greenhouse Gas Emissions and Renewable Energy. Energies 2019, 12, 3891. [CrossRef]

68. Ravina-Ripoll, R.; Tobar-Pesantez, L.B.; Marchena-Domínguez, J. A lighthouse for Social Wellbeing, Creativity and Sustainability: Happiness Management; Peter Lang: Bern, Switzerland, 2019.

69. Rehdanz, K.; Maddison, D. Climate and happiness. Ecol. Econ. 2005, 52, 111-125. [CrossRef]

70. Pillay, D. Happiness, wellbeing and ecosocialism-A radical humanist perspective. Globalizations 2019, 17, 380-396. [CrossRef]

71. Hernández-García de Velazco, J.J.; Chumaceiro-Hernández, A.C.; Ravina-Ripoll, R. Mirada transdisciplinaria de la participación ciudadana y la felicidad social en el discurrir del milenio. Rev. Utop. Prax. Latinoam. 2019, 24, 46-59. Available online: https:/ / produccioncientificaluz.org/index.php/utopia/article/view/29685 (accessed on 31 December 2020). 